\title{
Steroidogenic enzyme activities in the pre- and post-parturient equine placenta
}

\author{
Erin L Legacki ${ }^{1}$, C Jo Corbin¹, Barry A Ball², Kirsten E Scoggin², Scott D Stanley ${ }^{3}$ and \\ Alan J Conley ${ }^{1}$ \\ ${ }^{1}$ Department of Population Health \& Reproduction, School of Veterinary Medicine, University of California, Davis, \\ California, USA, ${ }^{2}$ Department of Veterinary Science, University of Kentucky, Lexington, Kentucky, USA and \\ ${ }^{3}$ Department of Molecular Biosciences, School of Veterinary Medicine, University of California, Davis, \\ California, USA \\ Correspondence should be addressed to A J Conley; Email: ajconley@ucdavis.edu
}

\begin{abstract}
Steroidogenic enzymes in placentas shape steroid hormone profiles in the maternal circulation of each mammalian species. These include $3 \beta$-hydroxysteroid dehydrogenase/ $\Delta 5$-4 isomerase (3 $\beta \mathrm{HSD}$ ) and $17 \alpha$-hydroxylase/17,20-lyase cytochrome P450 (P450c17) crucial for progesterone and androgen synthesis, respectively, as well as aromatase cytochrome P450 (P450arom) that converts $\Delta 4$-androgens to estrogens. $5 \alpha$-reductase is another important enzyme in equine placentas because $5 \alpha$-dihydroprogesterone (DHP) sustains pregnancy in the absence of progesterone in the second half of equine pregnancy. DHP and its metabolites decline dramatically days before foaling, but few studies have investigated placental enzyme activity before or at parturition in mares. Thus, key enzyme activities and transcript abundance were investigated in equine placentas at 300 days of gestation (GD300) and post-partum (term). Equine testis was used as a positive control for P450c17 activity. Substrates were incubated with microsomal preparations, together with enzyme inhibitors, and products were measured by liquid chromatography tandem mass spectrometry or radiometric methods (aromatase). Equine placenta expressed high levels of $3 \beta \mathrm{HSD}, 5 \alpha$-reductase and aromatase, and minimal P450c17 activity at GD300 compared with testis (600-fold higher). At foaling, 33HSD and aromatase activities and transcript abundance were unchanged but $5 \alpha$-reductase (and P450c17) was no longer detectable $(P<0.05)$ and transcript was decreased. Trilostane inhibited 3 $\beta$ HSD significantly more in testis than placenta, suggesting possible existence of different $3 \beta \mathrm{HSD}$ isoforms. Equine placentas have significant capacity for steroid metabolism by $5 \alpha$-reductase, $3 \beta \mathrm{HSD}$ and aromatase but little for androgen synthesis lacking P450c17. Declining pre-partum $5 \alpha$-reduced pregnane concentrations coincide with selective loss of placental $5 \alpha$-reductase activity and expression at parturition in horses.

Reproduction (2018) 155 51-59
\end{abstract}

\section{Introduction}

The mammalian placenta expresses an array of steroidogenic enzymes that ultimately shapes the unique profile of steroid hormones identifiable in the maternal circulation for each species. Those enzymes most crucial for placental sex steroid synthesis include 3 $\beta$-hydroxysteroid dehydrogenase/ $\Delta 5-4$ isomerase $(3 \beta \mathrm{HSD})$ and $17 \alpha$-hydroxylase/17,20lyase cytochrome P450 (P450c17) that are involved in progesterone and androgen synthesis, respectively, and aromatase cytochrome P450 (P450arom) that converts $\Delta 4$-androgens to estrogens (Conley \& Mason 1990, 1994, Conley \& Hinshelwood 2001). 5 $\alpha$-reductase is another important enzyme especially in the equine placenta because $5 \alpha$-reduced pregnanes dominate the steroid profile in the second half gestation (Holtan et al. 1991, Scholtz et al. 2014, Legacki et al. 2016a,b). Progesterone itself is undetectable after approximately
200 days of gestation, and the maintenance of pregnancy relies on the synthesis of $5 \alpha$-dihydroprogesterone (DHP) that activates the equine progesterone receptor with a biopotency equal to progesterone itself (Scholtz et al. 2014). Clearly, however, major differences exist in the types, patterns and concentrations of steroids secreted during gestation, even among closely related species, that reflect variations in the expression of placental steroidogenic enzymes (Geisert \& Conley 1998, Jenkin \& Young 2004, Mitchell \& Taggart 2009). For example, unlike humans, the placentas of rats and mice express P450c17, but they lack P450arom expression and thus androgens not estrogens are the major steroids secreted by the rodent placenta (Geisert \& Conley 1998). In contrast, the human and non-human primate placenta expresses high levels of P450arom but lacks expression of P450c17 and as a result must utilize fetal androgens for placental estrogen synthesis 
(Simpson \& MacDonald 1981, Conley et al. 2004). As in human pregnancies, estrogen synthesis in pregnant mares is fueled by fetal androgens, because the placenta is also believed to lack P450c17 expression and androgen synthetic capacity (Conley 2016). To date, this has not been thoroughly documented in the literature.

The endocrinology of equine pregnancy differs markedly from most other mammals (Conley 2016). During the second trimester of gestation in the mare, the concentration of maternal blood progesterone gradually decreases to the point that it becomes undetectable (Short 1959, Holtan et al. 1991, Legacki et al. 2016b). As progesterone concentrations decrease, there is a concomitant increase in $5 \alpha$-reduced pregnanes including $5 \alpha$-dihydroprogesterone (DHP) and associated metabolites (Holtan et al. 1991, Scholtz et al. 2014, Legacki et al. 2016b). The concentrations of DHP and multiple other $5 \alpha$-reduced metabolites increase in the second half of pregnancy, reaching peaks a few days before foaling, when concentrations suddenly fall (Seamans et al. 1979, Legacki et al. 2016a). This contrasts with estrogens, the concentrations of which do not change detectably until after parturition (Haluska \& Currie 1988, O'Donnell et al. 2003). The contrasting patterns of $5 \alpha$-reduced pregnane and estrogen concentrations around the time of parturition presumably reflect dynamic changes in enzyme activities in the placenta. To date, few studies have been conducted to characterize enzyme activities in the equine placenta (Ainsworth \& Ryan 1966, Pashen et al. 1982, Numazawa \& Osawa 1987, Marshall et al. 1989, 1996, 1999, Chavatte et al. 1995). None have reported quantitative estimates of activity, compared the activities of different enzymes or investigated the potential changes in them, before and at the time of parturition. Though transcript abundance (and immunoblot analyses) can provide insight into what might be regulating of expression of specific proteins (Legacki et al. 2017), reactions are dependent on multiple protein components including redox partners and accessory proteins (Conley \& Bird 1997, Corbin et al. 2001, Nguyen et al. 2009). Thus, transcript analysis of steroidogenic enzymes cannot accurately predict (or allow a comparison of) catalytic capacities, which is what ultimately determines steroid synthesis and the patterns of secretion that are unique to each species.

Therefore, the following studies were conducted to investigate the activities and transcript abundance of several key steroidogenic enzymes in equine placentas. The relative levels of activity of placental $3 \beta \mathrm{HSD}$, aromatase and $5 \alpha$-reductase were examined at day 300 of gestation (GD300) and at the time of parturition. The interval from GD300 to term represents a period during which the concentrations of $5 \alpha$-reduced pregnanes decrease dramatically (Legacki et al. 2016a). It was hypothesized that measuring placental enzyme activities prior to and at foaling would provide insight into the mechanisms regulating the dramatic changes in steroid concentrations seen over the last few days of gestation. In addition, we sought to confirm the lack of P450c17 enzyme activity in the equine placenta, published data for which is surprisingly scant (Mason et al. 1993), including information from a single placenta only in one published report (Ainsworth \& Ryan 1966). Equine testes were included in experiments as a positive control based on these previous studies and our recent observations indicating a relative lack of transcript abundance for P450c17 in equine placentas (Legacki et al. 2017).

\section{Materials and methods}

\section{Animals}

Experiments were approved by the Institutional Animal Use and Care Advisory Committee at the University of California, Davis (UCD) and the University of Kentucky, Lexington (UK), in accordance with the Guide for the Care and Use of Agricultural Animals in Agricultural Research and Teaching. Placental samples were recovered from normal mares killed at 300 days of gestation (GD300, $n=5,11.6 \pm 2.1$ years of age) and from term mares $(n=4,9.5 \pm 2.2$ years of age) after they were released. All mares were controls for unrelated studies conducted at the United Kingdom, as described previously (Legacki et al. 2017). Additional samples were collected from term placentas passed at foaling by mares stabled at UCD $(n=9)$ specifically for measuring aromatase activity. These were all quarter horses, aged $8.8 \pm 0.9$ years. Gestation lengths were normal ranging from around 330 to 343 days. All foals were alive and healthy at birth without any veterinary intervention or assistance. Testes were obtained at routine clinical castration from stallions $(n=4)$ of mixed breed and of unknown ages. All tissues were collected on ice until processed. Aliquots of tissues were frozen rapidly and stored until analyzed for steroidogenic enzyme activity. Additional aliquots were preserved in RNAlater (Thermo Fisher Scientific), refrigerated overnight $\left(4^{\circ} \mathrm{C}\right)$ and subsequently frozen at $-80^{\circ} \mathrm{C}$ until RNA isolation.

\section{Microsomal enrichment}

Equine placental and testicular tissues were homogenized in buffer $\left(0.1 \mathrm{M} \mathrm{K}_{3} \mathrm{PO}_{4}, \mathrm{pH} 7.4,20 \%\right.$ glycerol, $5 \mathrm{mM}$ $\beta$-mercaptoethanol, $0.5 \mathrm{mM}$ phenylmethylsulfonyl fluoride and $1 \mu \mathrm{g} / \mu \mathrm{L}$ aprotinin) and then briefly sonicated. Homogenates were centrifuged at $15,000 \mathrm{~g}$ for $10 \mathrm{~min}$ and supernatant was transferred to a new tube and centrifuged again at 100,000 $\mathrm{g}$ for $1 \mathrm{~h}$. The resulting microsomal pellet was recovered and resuspended. The concentrations of crude protein were determined using the Pierce BCA Protein Reagent (Thermo Scientific). Microsomal preparations were stored in aliquots at $-80^{\circ} \mathrm{C}$.

\section{Standards and solutions}

The following standards were purchased from Steraloids (Newport, RI, USA): 5 $\alpha$-dihydroprogesterone (DHP), 
allopregnanolone $(3 \alpha \mathrm{DHP})$, pregnenolone, $5 \alpha$-pregnan-3 $\beta, 20 \alpha$ diol $(3 \beta, 20 \alpha \mathrm{DHP}), \quad 20 \alpha$-hydroxy-5 $\alpha$-dihydroprogesterone $(20 \alpha \mathrm{DHP})$, progesterone and d9-progesterone. A master mix of all reference standards was prepared and diluted in methanol $(10,1,0.1$ and $0.01 \mathrm{ng} / \mathrm{mL})$. Methanol and water were of HPLC grade and obtained from Burdick and Jackson (Muskegon, MI, USA). Formic acid and methyl-tert buytl ether were of ACS grade and obtained from EMD (Gibbstown, NJ, USA).

\section{Enzyme activities}

All reactions were conducted with $10-12 \mu \mathrm{g}$ of microsomal protein in phosphate buffer $\left(50 \mathrm{mM} \mathrm{K} \mathrm{KO}_{4}, 1 \mathrm{mM}\right.$ EDTA, $\mathrm{pH}$ 7.4) with appropriate substrates. Parallel reactions were conducted with addition of enzyme inhibitors to verify that the steroids detected after incubation resulted from active synthesis. Placental $5 \alpha$-reductase activity in microsomes from GD300 and term placentas (as well as equine testes) were incubated with $3 \mu \mathrm{M}$ progesterone with and without finasteride $(100 \mu \mathrm{M}$; specific $5 \alpha$-reductase inhibitor) for $2 \mathrm{~h}$ at $37^{\circ} \mathrm{C}$ essentially as described previously for equine epididymis (Corbin et al. 2016). The activity of $17 \alpha$-hydroxylase/17,20lyase cytochrome P450 (P450c17) was assessed similarly by measuring the accumulation of $17 \alpha \mathrm{OH}$-progesterone and androstenedione from progesterone $(3 \mu \mathrm{M})$ substrate. Finasteride $(100 \mu \mathrm{M})$ was included as a control in $5 \alpha$-reductase assays to verify active synthesis. Finasteride also was included in all P450c17 assays to limit $5 \alpha$-reduced metabolism of progesterone. Ketoconazole $(100 \mu \mathrm{M})$, an inhibitor of cytochromes $\mathrm{P} 450$, was also added in the $\mathrm{P} 450 \mathrm{c} 17$ reactions to confirm active synthesis. Reactions for both $5 \alpha$-reductase and P450c17 activities were supported by co-incubation with NADPH and a generating system (1 mM NADP+, $10 \mathrm{mM}$ glucose-6-phosphate and 1.25 $U$ glucose-6-phosphate dehydrogenase). The activity of $3 \beta \mathrm{HSD}$ was examined essentially as described earlier (Conley et al. 2011), with minor modifications, from the accumulation of androstenedione from the added substrate, dehydroepiandrosterone (DHEA; $3 \mu \mathrm{M})$. Incubations were conducted in the presence of $1 \mathrm{mM}$ $\beta N A D$. Trilostane $(30 \mu \mathrm{M})$, a specific inhibitor of $3 \beta \mathrm{HSD}$, was used to verify active synthesis.

\section{Steroid product analysis}

The products of reactions for $5 \alpha$-reductase, P450c1 7 and $3 \beta$ HSD were extracted and analyzed by liquid chromatography tandem mass spectrometry as described in the following sections. This method detects progesterone, $17 \alpha \mathrm{OH}$-progesterone, androstenedione, DHEA, dihydrotestosterone (DHT), testosterone, DHP and several of its metabolites including allopregnanolone, $\quad 20 \alpha$-hydroxy- $5 \alpha$-dihydroprogesterone

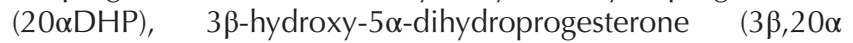
DHP), as well as estrone. Samples were extracted and prepared as previously described (Legacki et al. 2016b). Briefly, the progesterone-d9 internal standard was added to all samples that were extracted subsequently with methyl-tert buytl ether (1:5). Calibrators ranged from 0.1 to $100 \mathrm{ng} / \mathrm{mL}$ and four levels of quality controls (QC; 0.6, 1.5. 20 and $80 \mathrm{ng} / \mathrm{mL}$ ) were prepared alongside the samples, transferred into $12 \times 75$ glass tubes and dried in a Zymark TurboVap concentrator (Hopkinton, MA, USA) at $45^{\circ} \mathrm{C}$ under $\mathrm{N}_{2}$. Samples were reconstituted with $200 \mu \mathrm{L}$ of 50:50 mix of water and methanol.

The LC-MS/MS method used has been validated as described in detail (Legacki et al. 2016b). In brief, however, reverse-phase gradient separation was performed on an Agilent UHPLC C18 analytical column $(2.1 \times 50 \mathrm{~mm}, 1.8 \mu \mathrm{mps})$ with two mobile phases delivered at $0.4 \mathrm{~mL} / \mathrm{min}$, an injection volume of $20 \mu \mathrm{L}$ and a column temperature of $40^{\circ} \mathrm{C}$. Mobile phase $\mathrm{A}$ and $\mathrm{B}$ were water with $0.2 \%$ formic acid and methanol respectively. An elution gradient was held at $40 \%$ B for the first $0.2 \mathrm{~min}$, $40-60 \%$ B from 0.2 to $1 \mathrm{~min}, 60-80 \%$ B from 1 to $10 \mathrm{~min}$, $80-90 \%$ B from 10.0 to $10.1 \mathrm{~min}$, held at $90 \%$ B from 10.1 to $11.1 \mathrm{~min}, 90-40 \%$ from 11.1 to $11.2 \mathrm{~min}$ and held at $40 \% \mathrm{~B}$ until $13.10 \mathrm{~min}$. Ionization achieved utilized an atmospheric pressure chemical ionization (APCI) source. Tandem mass spectral detection was accomplished using a Bruker EVOQ. Detection and quantitation of all analytes were accomplished using multiple reaction monitoring with a minimum of 2 transitions per analyte. Inter- and intra-accuracy and precision were assessed at four QC concentrations for all analytes (six replicates). All analytes were measured with $\leq 15 \%$ deviation from expected concentrations for the three highest QC concentrations $(1.5,20$ and $80 \mathrm{ng} / \mathrm{mL})$ and $\leq 15 \%$ coefficient of variation $(\% \mathrm{CV})$. For the lowest $\mathrm{QC}$ concentration $(0.6 \mathrm{ng} / \mathrm{mL})$ pregnenolone, $20 \alpha \mathrm{DHP}$ and $3 \beta, 20 \alpha \mathrm{DHP}$ had $\leq 20 \%$ deviation from expected concentrations. All analytes measured had a percent accuracy (\%Acc) $>90 \%$ and a precision $<15 \%$. The responses for all analytes were linear and gave correlation coefficients $\left(R^{2}\right)$ of $>0.99$.

\section{Aromatase activity}

Aromatase activity was measured radiometrically as validated and reported previously (Corbin et al. 2001) by monitoring the incorporation of tritium from $\left[1 \beta-{ }^{3} \mathrm{H}\right]$-androstenedione (PerkinElmer) into ${ }^{3} \mathrm{H}_{2} \mathrm{O}$. All reactions were conducted with $10 \mu \mathrm{g}$ of microsomal protein and were incubated for $2 \mathrm{~h}$ at $37^{\circ} \mathrm{C}$ in the presence of $150 \mathrm{nM}$ androstenedione (10\% labeled, $90 \%$ cold; Steraloids, Wilton, $\mathrm{NH}$, USA) with a generating system $(1 \mathrm{mM}$ $\mathrm{NADP}+, 10 \mathrm{mM}$ glucose-6-phosphate and $1.25 \mathrm{U}$ glucose6-phosphate dehydrogenase). The assay was stopped with $30 \%$ cold trichloroacetic acid, extracted with chloroform and mixed with a suspension of 5\% charcoal and $0.5 \%$ dextran. After centrifugation at $2000 \mathrm{~g}$ for $30 \mathrm{~min}$, the amount of ${ }^{3} \mathrm{H}_{2} \mathrm{O}$ produced was quantified by scintillation counting. Letrozole $(1 \mu \mathrm{M})$ was used in parallel reactions to verify active synthesis.

\section{Transcript analysis by quantitative polymerase chain reaction ( $q P C R$ )}

Total cellular RNA was extracted from frozen allantochorion using the RNeasy Mini Kit (Qiagen) following the manufacturer's instructions. RNA purity and concentration were assessed using the Agilent bioanalyzer RNA 6000 Nano kit (Agilent Technologies) with RNA integrity values (RIN) above 8.8. Samples of RNA ( $1 \mu \mathrm{g} /$ reaction) were treated with rDNase I (Thermo Fisher Scientific) and then reverse transcribed using the TaqMan Reverse Transcription Reagents 
as described previously (Legacki et al. 2017). The mRNA expression of hydroxy- $\triangle 5$-steroid dehydrogenase (HSD3B1), cytochrome P450 family 19A1 (CYP19A1) and 5 $\alpha$-reductase 1 (SRD5A1) were quantified by real-time quantitative PCR (qPCR) using primers described and validated as previously reported (Legacki et al. 2017). PCR efficiencies were calculated using LinRegPCR (version 2013.0; (Ruijter et al. 2009)). All reactions were pipetted using the epMotion Automated Pipetting Systems (Eppendorf; Hauppauge, NY, USA). The $\Delta \mathrm{Ct}$ for each gene of interest was calculated by subtracting the CT of the housekeeping genes (geometric mean of $\beta$-actin $(A C T B)$ and $\beta$-glucuronidase (GUSB)) from the CT of the gene of interest. Gene expression data are presented as relative quantification values. Changes in relative abundance of specific transcripts were examined by calculating the $\Delta \mathrm{Ct}$ (Livak \& Schmittgen 2001).

\section{Statistical analysis}

Analysis of variance was conducted using the Proc Mixed procedure in SAS (SAS Statistical Software, SAS Institute Inc., Cary, NC, USA). The correlations among the steroids in tissues were determined with the Proc Corr procedure. Data that did not meet the standards for normality were log transformed before analysis. The data were graphed using the means and standard errors calculated for each steroid. Differences in abundance of mRNA of steroidogenic enzymes based on $\Delta \mathrm{Ct}$ values were examined using a two-tailed $t$-test in SAS. Differences among means and correlation coefficients were considered significant when $P<0.05$.

\section{Results}

Estimates of $5 \alpha$-reductase activity were based on the rate of accumulation of measured $5 \alpha$-reduced metabolites of progesterone, and there was robust activity in microsomes from placentas collected at GD300. 3 $\beta, 20 \alpha$ DHP was found in the greatest amounts, synthesized at a rate of $12.0 \pm 1.9 \mathrm{nmol} / \mathrm{mg} / \mathrm{h}$. Similarly, allopregnanolone was synthesized at rate of $3.5 \pm 0.8 \mathrm{nmol} / \mathrm{mg} / \mathrm{h}$ and DHP at $1.8 \pm 0.3 \mathrm{nmol} / \mathrm{mg} / \mathrm{h}$ in addition to trace amounts of $20 \alpha \mathrm{DHP}$ (Fig. 1). Finasteride, an inhibitor of $5 \alpha$-reductase activity, decreased the synthesis of all $5 \alpha$-reduced metabolites $(P<0.05)$ by $70 \%$ on average. In stark contrast to the active $5 \alpha$-reductase metabolism evident in microsomes from placentas collected at GD300, no $5 \alpha$-reduced progesterone metabolites were detected in incubations with the microsomal preparations from placentas collected at term (Fig. 1; $P<0.001$ ).

The same microsomal preparations from placentas collected at GD300 and at term demonstrated rapid synthesis of androstenedione from DHEA, a measure of $3 \beta \mathrm{HSD}$ activity. Androstenedione was synthesized at a rate of $165.0 \pm 9.8$ and $160.0 \pm 11.7 \mathrm{nmol} / \mathrm{mg} / \mathrm{h}$ in microsomes from placentas collected at GD300 and term, respectively. Trilostane, a specific inhibitor of $3 \beta \mathrm{HSD}$ enzyme activity, inhibited the synthesis

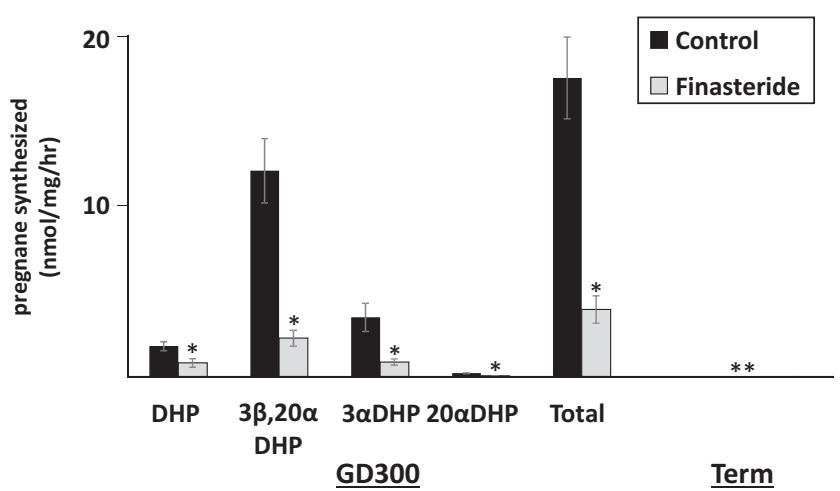

Figure $15 \alpha$-Reductase enzyme activity ( $\mathrm{nmol} / \mathrm{mg} / \mathrm{h}$ ) in microsomal preparations $(12 \mu \mathrm{g}$ protein) from equine placentas collected at 300 days of gestation (GD300) and at foaling (term) measured by metabolism of progesterone to $5 \alpha$-reduced products including dihydroprogesterone (DHP), 3 $\beta, 20 \alpha$-dihydroxy-DHP $(3 \beta, 20 \alpha \mathrm{DHP})$, allopregnanolone ( $3 \alpha \mathrm{DHP})$ and $20 \alpha$-hydroxy-DHP $(20 \alpha \mathrm{DHP})$, the sum of which is also shown (total). The $5 \alpha$-reduced metabolism of progesterone was conducted in the absence (control, black) or presence (finasteride, shaded) of a specific enzyme inhibitor to verify active synthesis. *Indicates finasteride-inhibited product formation $(P<0.05)$. **Note, no $5 \alpha$-reduced progesterone metabolites were detectable in incubations with microsomes from term placentas $(P<0.001)$.

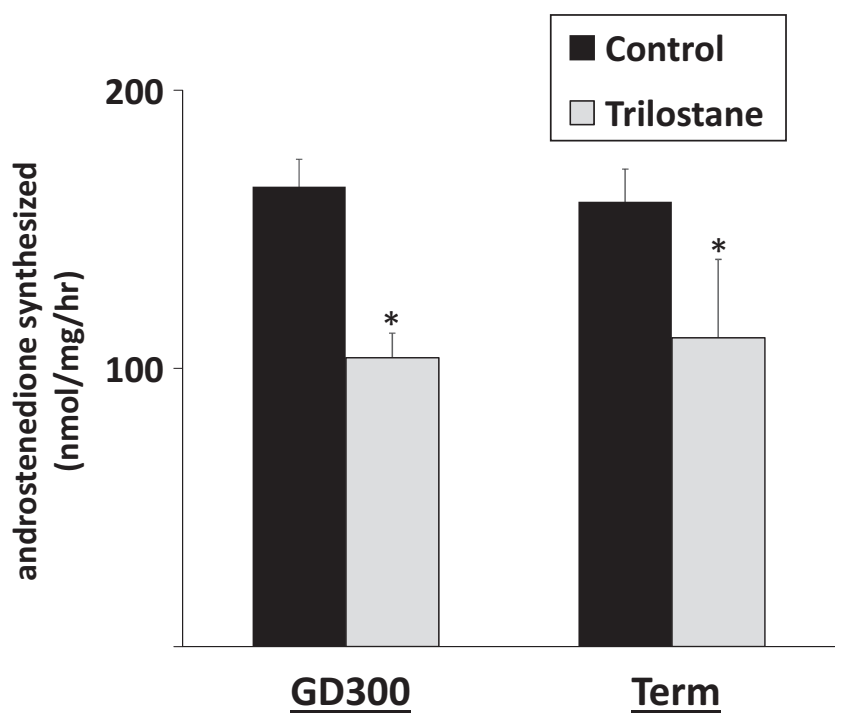

Figure $23 \beta$-Hydroxysteroid dehydrogenase/ $\Delta 5-4$ isomerase (3ßHSD) enzyme activity $(\mathrm{nmol} / \mathrm{mg} / \mathrm{h})$ in microsomal preparations (12 $\mu \mathrm{g}$ protein) from equine placentas collected at 300 days of gestation (GD300) and at foaling (term) measured by metabolism of dehydroepiandrosterone (DHEA) to androstenedione. The metabolism of DHEA to androstenedione by $3 \beta \mathrm{HSD}$ was conducted in the absence (control, black) or presence (trilostane, shaded) of a specific enzyme inhibitor to verify active synthesis. Note: there were no significant differences between microsomes from GD300 and term placentas in apparent $3 \beta \mathrm{HSD}$ activity. *Indicates trilostane inhibited androstenedione formation $(P<0.05)$. 


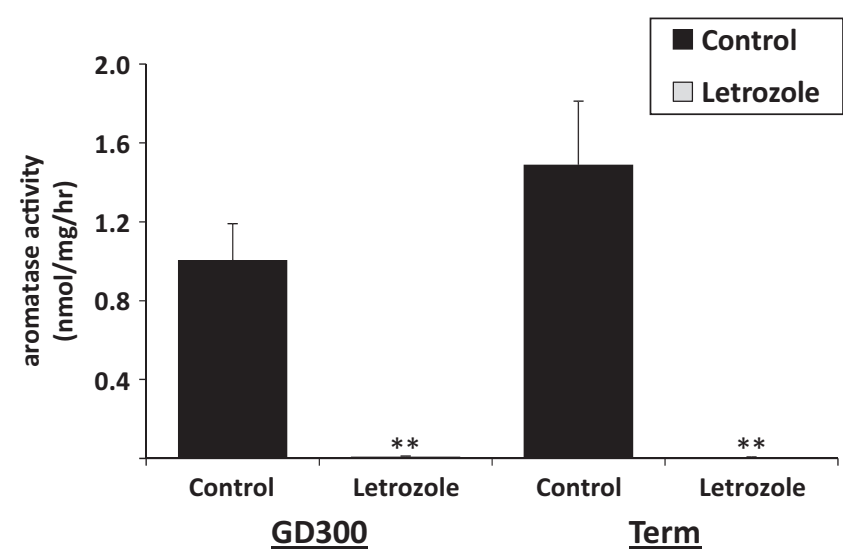

Figure 3 Aromatase activity $(\mathrm{nmol} / \mathrm{mg} / \mathrm{h}$ ) in microsomal preparations (12 $\mu \mathrm{g}$ protein) from equine placentas collected at 300 days of gestation (GD300) and at foaling (term) measured by the release of tritiated water following the aromatization of $[1 \beta-3 \mathrm{H}]-$ androstenedione. The metabolism of $[1 \beta-3 \mathrm{H}]$-androstenedione was conducted in the absence (control, black) or presence (letrozole, shaded) of a specific enzyme inhibitor to verify active synthesis. Note: there were no significant differences between microsomes from GD300 and term placentas in apparent aromatase activity.

**Indicates letrozole inhibited aromatase activity $(P<0.01)$.

of androstenedione $(P<0.05)$ by 30 and $37 \%$ in the GD300 and term microsomes respectively (Fig. 2). There was no significant difference in $3 \beta \mathrm{HSD}$ enzyme activity between the GD300 and term placental microsomes.

Aromatase activity, determined by the release of ${ }^{3} \mathrm{H}_{2} \mathrm{O}$ from tritiated androstenedione, was also detectable in placental microsomes from GD300 and term placentas and was inhibited $>99 \%$ by letrozole (Fig. $3 ; P<0.01$ ). The variability of the measured activity among the term placentas from the UK mares was extreme (0.01$2.25 \mathrm{nmol} / \mathrm{mg} / \mathrm{h}$ ). Consequently, additional samples were collected from mares foaling at UCD, which were assayed for comparison with similar results. Aromatase activity in the term placental samples from UCD exhibited a similarly wide range, from 0.01 to $3.01 \mathrm{nmol} / \mathrm{mg} / \mathrm{h}$. The data were combined and the levels of aromatase activity in microsomes from placentas collected at GD300 and at term $(1.49 \pm 0.32$ and $1.01 \pm 0.18 \mathrm{nmol} /$ $\mathrm{mg} / \mathrm{h}$, respectively) were not significantly different from one another.
Incubations conducted in placental microsomes with progesterone as substrate in the presence of finasteride were examined for the synthesis of $17 \alpha \mathrm{OH}$ progesterone and androstenedione, as evidence of $17 \alpha$-hydroxylase/17,20-lyase (P450c17) activity. There was detectable $17 \alpha \mathrm{OH}$-progesterone in incubations of microsomes from placentas collected at GD300, which was completely abolished by addition of ketoconazole, an inhibitor of cytochrome P450 activity. Based on $17 \alpha \mathrm{OH}$-progesterone accumulation in incubations with these specimens, the rate of P450c17 enzyme activity was detectable $(0.08 \pm 0.03 \mathrm{nmol} / \mathrm{mg} / \mathrm{h}$; Table 1$)$. No androstenedione or testosterone was detected, even in the absence of ketoconazole. In contrast to placentas from GD300, there was no detectable metabolism of progesterone to $17 \alpha \mathrm{OH}$-progesterone or androstenedione in any of the microsomal preparations from term placentas.

Testicular microsomes were examined for P450c17 enzyme activity (Table 1) using the same incubation conditions as for placental microsomes. Progesterone was metabolized to $17 \alpha \mathrm{OH}$-progesterone, androstenedione and testosterone at rates of $30.5 \pm 16.6,20.7 \pm 8.7$ and $3.4 \pm 1.1 \mathrm{nmol} / \mathrm{mg} / \mathrm{h}$ respectively. Product synthesis was inhibited in the presence of ketoconazole by $80 \%$ overall $(P<0.01)$. Additional incubations were also conducted with DHEA as substrate to measure $3 \beta \mathrm{HSD}$ enzyme activity and with $\left[1 \beta-{ }^{3} \mathrm{H}\right]$-androstenedione to measure aromatase activity. Apparent $3 \beta \mathrm{HSD}$ activity was $45.0 \pm 22.7 \mathrm{nmol} / \mathrm{mg} / \mathrm{h}$, which was reduced to $9.3 \pm 4.4 \mathrm{nmol} / \mathrm{mg} / \mathrm{h}$ in the presence of trilostane, also over $80 \%$ inhibition of enzyme activity $(P<0.01)$. Aromatase activity in testicular microsomes averaged $0.44 \pm 0.41 \mathrm{nmol} / \mathrm{mg} / \mathrm{h}$ and was almost completely inhibited by letrozole ( $>99 \%$ ).

The quality of RNA isolated from placentas collected from mares at GD300 and post-parturiently was high overall $(9.4 \pm 0.2$ and $9.4 \pm 0.3$ respectively, 10 point scale), and essentially identical. The abundance of transcript encoding P450arom (CYP19A1) and 3 $\beta$-HSD (HSD3B1) in the pre- and post-parturient placentas were not different (Table 2). However, the abundance of transcript encoding $5 \alpha$-reductase (SRD5A1) was significantly lower (higher $\Delta \mathrm{Ct}$ ) in the post-parturient placentas than that of the placentas collected at GD300 (Table 2; $P<0.05$ ).

Table 1 Progesterone metabolism to $17 \mathrm{OH}$-progesterone, androstenedione and testosterone ( $\mathrm{P} 450 \mathrm{c} 17$ activity, $\mathrm{nmol} / \mathrm{mg} / \mathrm{h}$ ) in microsomes from placentas (day 300 of gestation, $n=5)$ and testes $(n=4)$, in the presence or not of ketoconazole, an enzyme inhibitor.

\begin{tabular}{lcccc}
\hline Tissue & $\mathbf{1 7 O H}$-progesterone & Androstenedione & Testosterone & Total \\
\hline Placenta & $0.08 \pm 0.03^{\mathrm{a}}$ & $0^{\mathrm{a}}$ & $0^{\mathrm{a}}$ & $0.08 \pm 0.03^{\mathrm{a}}$ \\
Placenta + keto & $0^{\mathrm{b}}$ & $0^{\mathrm{a}}$ & $0^{\mathrm{a}}$ & $0^{\mathrm{b}}$ \\
Testis & $40.3 \pm 22.0^{\mathrm{c}}$ & $23.7 \pm 10.0^{\mathrm{b}}$ & $3.9 \pm 1.1^{\mathrm{b}}$ & $67.9 \pm 32.4^{\mathrm{c}}$ \\
Testis + keto & $8.3 \pm 5.4^{\mathrm{d}}$ & $2.8 \pm 0.9^{\mathrm{c}}$ & $1.2 \pm 0.1^{\mathrm{c}}$ & $12.3 \pm 3.4^{\mathrm{d}}$ \\
\hline
\end{tabular}

Finasteride $(100 \mu \mathrm{M})$ was included in incubations with placental microsomes to minimize $5 \alpha$-reductase activity that was minimal in preparations from testes.

$a, b, c, d$ Within columns (steroid products), means with different superscripts differ, $P<0.01$. 
Table 2 Relative mRNA transcript abundance for CYP19A1 (encodes aromatase cytochromes P450), HSD3B1 (encodes $3 \beta$-hydroxysteroid dehydrogenase/ $\triangle 5-4$ isomerase), and SRD5A 1 (encodes $5 \alpha$-reductase type 1 ) in equine chorioallantois at 10 months gestational age $(n=4)$ and postpartum $(n=4)$.

\begin{tabular}{lcr}
\hline & GD300 & \multicolumn{1}{c}{ Term } \\
\hline CYP19A1 & $-8.05 \pm 0.40$ & $-5.82 \pm 1.77$ \\
HSD3B1 & $-0.46 \pm 0.80$ & $-2.31 \pm 0.90$ \\
SRD5A1 & $3.39 \pm 0.59^{\mathrm{a}}$ & $8.27 \pm 0.69$ \\
\hline
\end{tabular}

Data expressed as mean ( \pm S.E.M.) $\Delta$ Ct as determined by quantitative polymerase chain reaction (qPCR) using the geometric mean of $\beta$-actin $(A C T B)$ and $\beta$-glucuronidase (GUSB) as reference transcripts. Lower values of $\triangle \mathrm{Ct}$ represent higher mRNA expression.

a Values differ between GD300 and post-parturient (term) placentas $(P<0.05)$.

\section{Discussion}

The equine placenta is thought to be reliant on the fetus for the provision of steroid substrates that it cannot synthesize in sufficient quantities itself for the lack of expression of the requisite enzymes (Conley 2016, Legacki et al. 2017). The best known and documented example is the provision of DHEA by the fetal gonads, which is used by the placenta for the synthesis of estrogens (Pashen \& Allen 1979, Raeside et al. 1979). The equine placenta is thought to be incapable of synthesizing androgens de novo, though data supporting this view are scant (Ainsworth \& Ryan 1966, Mason et al. 1993). We have previously reported that the transcript abundance of CYP17A1, the gene encoding P450c17 the enzyme required for androgen synthesis, was extremely low in placenta compared with fetal gonads and adrenal glands (Legacki et al. 2017). The results of the current studies are consistent with these data, quantitatively demonstrating that the level of androgen synthesis from progesterone by placental microsomes is trivial compared with the capacity of testicular microsomes. However, the placenta can utilize fetal DHEA by virtue of expressing 3ßHSD (Pashen et al. 1982, Mason et al. 1993, Chavatte et al. 1995) and aromatase (Ainsworth \& Ryan 1966, Mason et al. 1993, Marshall et al. 1996, 1999) activity, which the current results also confirm is robust pre- and post-partum. In addition, the placenta is thought to utilize pregnenolone derived from the fetus for $5 \alpha$-reduced pregnane synthesis based on high concentrations delivered via the umbilical artery and markedly lower concentrations in the umbilical vein (Ousey et al. 2003). This is consistent with very low CYP11A1 transcript abundance in placenta compared with the fetal adrenals and gonads (Legacki et al. 2017). The results of these recent studies suggest further that the fetal gonads are likely a significant source of the high concentrations of pregnenolone seen in the fetal circulation (Legacki et al. 2017). Collectively then, the supply of pregnenolone and DHEA by the equine fetus compensates for the relative lack of transcripts encoded by CYP11A1 and CYP17A1 in the placenta and supports both $5 \alpha$-reduced pregnane and estrogen synthesis during equine pregnancy. This is an unusual and particularly complex example of a feto-placental unit that is required to support steroid synthesis during gestation.

In addition to clarifying the enzymatic basis for placental pregnane and estrogen synthesis during pregnancy, the results of the current study also provide insight into mechanisms involved in the observed decline in $5 \alpha$-reduced pregnane concentrations that precede foaling in mares (Legacki et al. 2016a). The ability of the equine placenta to $5 \alpha$-reduce progesterone has been demonstrated in vitro (Hamon et al. 1991) and in situ (Moss et al. 1979, Marshall et al. 1999), but none to our knowledge have examined the enzyme activity at parturition. The presented data indicate that the capacity for $5 \alpha$-reduction disappears at the time of parturition though the capacity for metabolism of $\Delta 5$ steroids (pregnenolone and DHEA) by $3 \beta \mathrm{HSD}$ does not change at term from levels seen at GD300. Furthermore, the utilization of $\Delta 4$ androgens (androstenedione) for estrogen synthesis by aromatase in the placenta also remained unchanged. The maintenance of $3 \beta \mathrm{HSD}$ and aromatase enzyme activities argues strongly that the loss of $5 \alpha$-reductase in term placentas is not due to a general decline of placental enzymatic function at parturition. Similarly, it is unlikely to simply reflect tissue devitalization or protein deterioration after placental delivery given the high quality of RNA extracted and the correspondence between $5 \alpha$-reductase activity and $S R D 5 A 1$ transcript abundance, which was also lower in post-partum than GD300 placentas. Rather, these data suggest collectively that there is a selective reduction of $5 \alpha$-reductase in the placenta and is consistent with the dramatic decline in $5 \alpha$-reduced pregnanes in mares prior to foaling (Legacki et al. 2016a). Earlier studies have clearly documented the induction of expression of P450c17 and P450arom in the ovine placenta that fuels increased estrogen synthesis before parturition (Anderson et al. 1975, Flint et al. 1975, France et al. 1988, Mason et al. 1989). Cows may also exhibit an induction of CYP17A1 preceding parturition (Shenavai et al. 2012). The opposite appears to be the case in the mare. In fact, the authors are unaware of any evidence for selective suppression of placental steroidogenic enzyme expression as a prelude to parturition in any species.

One of the concerns of the present experiment remains the potential for agonal degradation of placental tissues and associated steroidogenic enzyme activities during the interval from whenever endometrial separation occurred and the placenta was delivered to the time of collection. The major factor would be the onset of tissue anoxia that follows the lack of perfusion and the time before autolysis or necrosis begins. The placental tissues collected in Davis were within a few minutes of passage as these mares and their foals were under close and constant observation, but may have been hours in the case of 
the tissues collected in Lexington. Placental enzyme activities measured after microsomal isolation were robust in both cases nonetheless. Since $5 \alpha$-reductase is in the microsomal fraction (Corbin et al. 2016), like $3 \beta \mathrm{HSD}$ and aromatase (Conley et al. 2011), loss of activity due to necrosis or autolysis would be expected to affect this and all in that cellular compartment, not any one activity selectively, as noted earlier. Moreover, placental tissue is unusually resistant to anoxia (Schneider 2009). The high RIN values from isolated placental transcripts in this study are consistent with maintenance of cellular integrity until the time of tissue collection and processing. The RIN values observed compared very favorably to those of RIN values for human placental samples collected and stored under ideal conditions (Martin et al. 2017). Metabolic changes can be detected within a few minutes following separation of the human placenta from their uterine blood supply (Cirelli et al. 2000, Serkova et al. 2003). These metabolic responses can include a halving or more of adenosine triphosphate concentrations rapidly (Serkova et al. 2003). Yet, re-perfusion after as much as $3 \mathrm{~h}$ of anoxia is followed by normalization of those cellular parameters (Schneider 2009) suggesting cellular viability is maintained. Consistent with these published observations, viable trophoblast for cell culture and perfusion can be isolated successfully from bovine placentas hours after collection (Conley \& Ford 1987), further verifying that there is an extended period of tissue viability after loss of placental perfusion. However, to what degree enzyme activities in postparturient placentas reflect those in placentas in the days immediately preceding parturition in mares will require additional, very carefully timed studies.

Lastly, it is noteworthy that the inhibition of $3 \beta \mathrm{HSD}$ by trilostane was markedly more effective in testicular than in placental microsomes even though levels of activity were robust in both, within an order of magnitude of each other. To date, there is no evidence for the existence of multiple isoforms of $3 \beta \mathrm{HSD}$ in the horse as there is in human and other species. However, there are differences in the sensitivity of human isoforms encoded by HSD3B1 and HSD $3 B 2$ to trilostane as well as differences in the mode of inhibition (Thomas et al. 2004). Similar observations of differential sensitivity of enzyme activity led to the discovery of isoforms of aromatase (Corbin et al. 1995). It is of interest to note that investigators have previously reported substantial differences between the equine placenta and equine fetal adrenal glands in the rates of utilization of pregnenolone and DHEA as substrates for $3 \beta \mathrm{HSD}$ activity. Fetal adrenal tissues converted far less pregnenolone to progesterone than they did DHEA to androstenedione, whereas placental $3 \beta \mathrm{HSD}$ utilized both substrates to a similar degree (Pashen et al. 1982). Kinetic studies on placental and testicular microsomes would be necessary to properly investigate the evidence for the possible existence of multiple equine $H S D 3 B$ isoforms and would require molecular studies to verify it, as for the porcine aromatases (Corbin et al. 1999, 2001). Such studies are well beyond the scope of those conducted but remain an intriguing possibility suggested by the apparent differences in sensitivity of placental compared with testicular $3 \beta \mathrm{HSD}$ to inhibition by trilostane. If true, this would represent yet another similarity between mares and women in steroidogenesis during pregnancy (Conley 2016).

In conclusion, the data presented quantify activities of several enzymes in the equine placenta before and at the time of parturition for the first time. The equine placenta has a pronounced capacity for steroid metabolism by expression of $5 \alpha$-reductase, $3 \beta \mathrm{HSD}$ and aromatase activities but has little capacity for androgen synthesis lacking significant P450c17 activity. Parturition is associated with a selective loss of $5 \alpha$-reductase activity and transcript abundance without any such changes in either $3 \beta \mathrm{HSD}$ or aromatase. The loss of placental $5 \alpha$-reductase activity and expression is consistent with the dramatic decline in $5 \alpha$-reduced pregnane metabolites that occurs in the days before foaling and likely contributes substantially to it.

\section{Declaration of interest}

The authors declare that there is no conflict of interest that could be perceived as prejudicing the impartiality of the research reported.

\section{Funding}

This research did not receive any specific grant from any funding agency in the public, commercial or not-for-profit sector.

\section{Acknowledgements}

The authors acknowledge the generous support of the John $P$ Hughes and Albert G Clay Endowments that funded these studies. The sampling of mares at the University of California, Davis was conducted by Joel Viloria and undergraduate students from the Department of Animal Science without whose help these studies could not have been completed. The authors are extremely grateful for the help and guidance of the technical staff at the Equine Analytical Chemistry Laboratory, School of Veterinary Medicine, University of California, Davis, especially the efforts and support of Daniel McKemie, Teresa Bowers, Dr Go Sugiarto and Sandy Yim, providing expertise, training and technical support for analysis of samples by liquid chromatography tandem mass spectroscopy. The authors also wish to thank Dr Alex Esteller-Vico, Dr Shavahn Loux, and Michelle Wynn for their assistance with tissue collection. 


\section{References}

Ainsworth L \& Ryan KJ 1966 Steroid hormone transformations by endocrine organs from pregnant mammals I. Estrogen biosynthesis by mammalian placental preparations in vitro. Endocrinology 79 875-883. (https://doi. org/10.1210/endo-79-5-875)

Anderson AB, Flint AP \& Turnbull AC 1975 Mechanism of action of glucocorticoids in induction of ovine parturition: effect on placental steroid metabolism. Journal of Endocrinology 66 61-70. (https://doi. org/10.1677/joe.0.0660061)

Chavatte PM, Rossdale PD \& Tait AD 1995 Modulation of 3 betahydroxysteroid dehydrogenase (3 beta-HSD) activity in the equineplacenta by pregnenolone and progesterone metabolites. Equine Veterinary Journal 27 342-347. (https://doi.org/10.1111/j.2042-3306.1995. tb04068.x)

Cirelli N, Lebrun P, Gueuning C, Moens A, Delogne-Desnoeck J, Dictus-Vermeulen C, Vanbellinghen A \& Meuris S 2000 Secretory characteristics and viability of human term placental tissue after overnight cold preservation. Human Reproduction 15 756-761. (https://doi.org/10.1093/humrep/15.4.756)

Conley AJ 2016 Review of the reproductive endocrinology of the pregnant and parturient mare. Theriogenology 86 355-365. (https://doi. org/10.1016/j.theriogenology.2016.04.049)

Conley AJ \& Bird IM 1997 The role of cytochrome P450 17 alphahydroxylase and 3 beta-hydroxysteroid dehydrogenase in the integration of gonadal and adrenal steroidogenesis via the delta 5 and delta 4 pathways of steroidogenesis in mammals. Biology of Reproduction 56 789-799. (https://doi.org/10.1095/biolreprod56.4.789)

Conley AJ \& Ford SP 1987 Effect of prostaglandin F2 alpha-induced luteolysis on in vivo and in vitro progesterone production by individual placentomes of cows. Journal of Animal Science 65 500-507. (https://doi.org/10.2527/jas1987.652500x)

Conley A \& Hinshelwood M 2001 Mammalian aromatases. Reproduction 121 685-695. (https://doi.org/10.1530/rep.0.1210685)

Conley AJ \& Mason JI 1990 Placental steroid hormones. Baillière's Clinical Endocrinology and Metabolism 4 249-272. (https://doi.org/10.1016/ S0950-351X(05)80050-3)

Conley AJ \& Mason JI 1994 Endocrine function of the placenta. In Textbook of Fetal Physiology, pp 16-29. Baillière Tindall: London, UK

Conley AJ, Pattison JC \& Bird IM 2004 Variations in adrenal androgen production among (nonhuman) primates. Seminars in Reproductive Medicine 22 311-326. (https://doi.org/10.1055/s-2004-861548)

Conley AJ, Corbin CJ, Thomas JL, Gee NA, Lasley BL, Moeller BC, Stanley SD \& Berger T 2011 Costs and consequences of cellular compartmentalization and substrate competition among human enzymes involved in androgen and estrogen synthesis. Biology of Reproduction 86 1-8.

Corbin CJ, Khalil MW \& Conley AJ 1995 Functional ovarian and placental isoforms of porcine aromatase. Molecular and Cellular Endocrinology 113 29-37. (https://doi.org/10.1016/0303-7207(95)03607-9)

Corbin CJ, Trant JM, Walters KW \& Conley AJ 1999 Changes in testosterone metabolism associated with the evolution of placental and gonadal isozymes of porcine aromatase cytochrome P450. Endocrinology $\mathbf{1 4 0}$ 5202-5210. (https://doi.org/10.1210/endo.140.11.7140)

Corbin CJ, Trant JM \& Conley AJ 2001 Porcine gonadal and placental isozymes of aromatase cytochrome P450: sub-cellular distribution and support by NADPH-cytochrome P450 reductase. Molecular and Cellular Endocrinology 172 115-124. (https://doi.org/10.1016/S03037207(00)00373-7)

Corbin CJ, Legacki E, Ball BA, Scoggin KE, Stanley SD \& Conley AJ 2016 Equine epididymal $5 \alpha$-reductase expression and activity. Journal of Endocrinology 231 23-33. (https://doi.org/10.1530/JOE-16-0175)

Flint AP, Goodson JD \& Turnbull AC 1975 Increased concentrations of 17alpha, 20alpha-dihydroxypregn-4-en-3-one in maternal and foetal plasma near parturition in sheep. Journal of Endocrinology 67 89-97.

France JT, Magness RR, Murry BA, Rosenfeld CR \& Mason JI 1988 The regulation of ovine placental steroid 17 alpha-hydroxylase and aromatase by glucocorticoid. Molecular Endocrinology 2 193-199.

Geisert RD \& Conley AJ 1998. Secretion and metabolism of steroids in subprimate mammals during pregnancy. In The Endocrinology of Pregnancy, pp 291-318. Springer: New York, USA
Haluska GJ \& Currie WB 1988 Variation in plasma concentrations of oestradiol-17 beta and their relationship to those of progesterone, 13,14-dihydro-15-keto-prostaglandin F-2 alpha and oxytocin across pregnancy and at parturition in pony mares. Journal of Reproduction and Fertility 84 635-646.

Hamon M, Clarke SW, Houghton E, Fowden AL, Silver M, Rossdale PD, Ousey JC \& Heap RB 1991 Production of 5 alpha-dihydroprogesterone during late pregnancy in the mare. Journal of Reproduction and Fertility Supplement 44 529-535.

Holtan DW, Houghton E, Silver M, Fowden AL, Ousey J \& Rossdale PD 1991 Plasma progestagens in the mare, fetus and newborn foal. Journal of Reproduction and Fertility Supplement 44 517-528.

Jenkin G \& Young IR 2004 Mechanisms responsible for parturition; the use of experimental models. Animal Reproduction Science 82-83 567-581. (https://doi.org/10.1016/j.anireprosci.2004.05.010)

Legacki EL, Corbin CJ, Scoggin KE, Ball BA, Stanley SD \& Conley AJ 2016a Endocrine preparation for equine parturition. Reproduction 152 323-331. (https://doi.org/10.1530/REP-16-0227)

Legacki EL, Scholtz EL, Ball BA, Stanley SD, Berger T \& Conley AJ 2016b The dynamic steroid landscape of equine pregnancy mapped by mass spectrometry. Reproduction 151 421-430. (https://doi.org/10.1530/REP15-0547)

Legacki EL, Ball BA, Corbin CJ, Loux SC, Scoggin KE, Stanley SD \& Conley AJ 2017 Equine fetal adrenal, gonadal and placental steroidogenesis. Reproduction 154 445-454.

Livak KJ \& Schmittgen TD 2001 Analysis of relative gene expression data using real-time quantitative PCR and the 2(-Delta Delta C(T)) Method. Methods 25 402-408. (https://doi.org/10.1006/meth.2001.1262)

Marshall DE, Gower DB, Houghton E \& Dumasia MC 1989 Studies of testosterone metabolism in equine placental tissue. Biochemical Society Transactions 17 1018-1019. (https://doi.org/10.1042/bst0171018)

Marshall DE, Dumasia MC, Wooding P, Gower DB \& Houghton E 1996 Studies into aromatase activity associated with fetal allantochorionic and maternal endometrial tissues of equine placenta. Identification of metabolites by gas chromatography mass spectrometry. Journal of Steroid Biochemistry and Molecular Biology 59 281-296. (https://doi. org/10.1016/S0960-0760(96)00115-X)

Marshall DE, Gower DB, Silver M, Fowden A \& Houghton E 1999 Cannulation in situ of equine umbilicus. Identification by gas chromatography-mass spectrometry (GC-MS) of differences in steroid content between arterial and venous supplies to and from the placental surface. Journal of Steroid Biochemistry and Molecular Biology 68 219-228. (https://doi.org/10.1016/S0960-0760(99)00034-5)

Martin NM, Cooke KM, Radford CC, Perley LE, Silasi M \& Flannery CA 2017 Time course analysis of RNA quality in placenta preserved by RNAlater or flash freezing. American Journal of Reproductive Immunology Epub. (https://doi.org/10.1111/aji.12637)

Mason JI, France JT, Magness RR, Murry BA \& Rosenfeld CR 1989 Ovine placental steroid 17 alpha-hydroxylase/C-17,20-lyase, aromatase and sulphatase in dexamethasone-induced and natural parturition. Journal of Endocrinology 122 351-359. (https://doi.org/10.1677/joe.0.1220351)

Mason JI, Hinshelwood M, Murry BA \& Swart P 1993 Tissue specific expression of steroid 17alpha-hydroxylase, C-17,20-lyase, 3betahydroxysteroid dehydrogenase and aromatase in the fetal horse. Society for Gynecological Investigation Proceedings P350.

Mitchell BF \& Taggart MJ 2009 Are animal models relevant to key aspects of human parturition? American Journal of Physiology: Regulatory, Integrative and Comparative Physiology 297 R525-R545. (https://doi. org/10.1152/ajpregu.00153.2009)

Moss GE, Estergreen VL, Becker SR \& Grant BD 1979 The source of the 5-alpha-pregnanes that occur during gestation in mares. Journal of Reproduction and Fertility Supplement 27 511-519.

Nguyen AD, Corbin CJ, Pattison JC, Bird IM \& Conley AJ 2009 The developmental increase in adrenocortical 17,20-lyase activity (biochemical adrenarche) is driven primarily by increasing cytochrome b5 in neonatal rhesus macaques. Endocrinology 150 1748-1756. (https://doi.org/10.1210/en.2008-1303)

Numazawa M \& Osawa Y 1987 Equilin and equilenin biosynthesis. Stereochemistry of aromatization of 3-hydroxy-3,5,7-androstatrien-17one by horse placenta. Journal of Steroid Biochemistry 26 137-143. (https://doi.org/10.1016/0022-4731(87)90042-2) 
O'Donnell LI, Sheerin BR, Hendry JM, Thatcher MJ, Thatcher WW \& LeBlanc MM 2003 24-Hour secretion patterns of plasma oestradiol 17 beta in pony mares in late gestation. Reproduction in Domestic Animals 38 233-235.

Ousey JC, Forhead AJ, Rossdale PD, Grainger L, Houghton E \& Fowden AL 2003 Ontogeny of uteroplacental progestagen production in pregnant mares during the second half of gestation. Biology of Reproduction 69 540-548. (https://doi.org/10.1095/biolreprod.102.013292)

Pashen RL \& Allen WR 1979 The role of the fetal gonads and placenta in steroid production, maintenance of pregnancy and parturition in the mare. Journal of Reproduction and Fertility Supplement 27 499-509.

Pashen RL, Sheldrick EL, Allen WR \& Flint AP 1982 Dehydroepiandrosterone synthesis by the fetal foal and its importance as an oestrogen precursor. Journal of Reproduction and Fertility Supplement 32 389-397.

Raeside JI, Liptrap RM, McDonell WN \& Milne FJ 1979 A precursor role for DHA in a feto-placental unit for oestrogen formation in the mare. Journal of Reproduction and Fertility Supplement 27 493-497.

Ruijter JM, Ramakers C, Hoogaars WM, Karlen Y, Bakker O, van den Hoff MJ \& Moorman AF 2009 Amplification efficiency: linking baseline and bias in the analysis of quantitative PCR data. Nucleic Acids Research 37 e45. (https://doi.org/10.1093/nar/gkp045)

Schneider H 2009 Tolerance of human placental tissue to severe hypoxia and its relevance for dual ex vivo perfusion. Placenta 30 (Supplement A) S71-S76. (https://doi.org/10.1016/j.placenta.2008.11.004)

Scholtz EL, Krishnan S, Ball BA, Corbin CJ, Moeller BC, Stanley SD, McDowell KJ, Hughes AL, McDonnell DP \& Conley AJ 2014 Pregnancy without progesterone in horses defines a second endogenous biopotent progesterone receptor agonist, 5alpha-dihydroprogesterone. PNAS 111 3365-3370. (https://doi.org/10.1073/pnas.1318163111)

Seamans KW, Harms PG, Atkins DT \& Fleeger JL 1979 Serum levels of progesterone, 5 alpha-dihydroprogesterone and hydroxy-5 alpha-pregnanones in the prepartum and postpartum equine. Steroids $\mathbf{3 3}$ 55-63. (https://doi.org/10.1016/S0039-128X(79)80006-9)

Serkova N, Bendrick-Peart J, Alexander B \& Tissot van Patot MC 2003 Metabolite concentrations in human term placentae and their changes due to delayed collection after delivery. Placenta 24 227-235. (https://doi.org/10.1053/plac.2002.0908)

Shenavai S, Preissing S, Hoffmann B, Dilly M, Pfarrer C, Ozalp GR, Caliskan C, Seyrek-Intas K \& Schuler G 2012 Investigations into the mechanisms controlling parturition in cattle. Reproduction 144 279-292. (https://doi.org/10.1530/REP-11-0471)

Short RV 1959 Progesterone in blood IV. Progesterone in the blood of mares. Journal of Endocrinology 19 207-210. (https://doi.org/10.1677/ joe.0.0190207)

Simpson ER \& MacDonald PC 1981 Endocrine physiology of the placenta. Annual Review of Physiology 43 163-188. (https://doi.org/10.1146/ annurev.ph.43.030181.001115)

Thomas JL, Duax WL, Addlagatta A, Kacsoh B, Brandt SE \& Norris WB 2004 Structure/function aspects of human 3beta-hydroxysteroid dehydrogenase. Molecular and Cellular Endocrinology 215 73-82. (https://doi.org/10.1016/j.mce.2003.11.018)

Received 29 July 2017

First decision 2 September 2017

Revised manuscript received 5 October 2017

Accepted 23 October 2017 